\title{
INVESTIGATION OF ISOBUTANE DEHYDROGENATION ON CrOx/MCM-41 CATALYST
}

\author{
Zuhal Erol ${ }^{1}$, Saliha Çetinyokuş Kılıçarslan², Meltem Doğan ${ }^{3}$ \\ ${ }^{1}$ Ministry of Labor and Social Security, Presidency of the Labor Inspection, 06520 Ankara, Turkey \\ ${ }^{2}$ Gazi University, Polymer Technology Department, 06374 Ankara, Turkey \\ ${ }^{3}$ Gazi University, Chemical Engineering Department, 06570 Ankara, Turkey \\ salihakilicarslan@gazi.edu.tr
}

\begin{abstract}
The syntheses of MCM-41 (Mobil Composition of Matter No. 41) supported chromium oxide catalysts at different chromium concentrations $(4-10 \%$ by mass) were carried out hydrothermally. The aim of this study was to determine the effect of chromium concentration in the catalyst structure on the chromate types and chromium oxidation states, as well as the activity of the catalyst in the isobutane dehydrogenation reaction. Inactive $\alpha-\mathrm{Cr}_{2} \mathrm{O}_{3}$ crystals for isobutane dehydrogenation were shown to increase in the catalyst structure as the chromium loading increased. The highest amount of $\mathrm{Cr}^{6+}$ on the catalyst surface was detected in the catalyst (H4-MCM-41) with $4 \%$ chromium by mass. Catalytic tests $\left(T=600{ }^{\circ} \mathrm{C}\right.$, $P=$ atmospheric pressure, WHSV $=26 \mathrm{~h}^{-1}$ ) were performed under fixed bed reactor conditions. The highest isobutane conversion ( 60\%) and selectivity ( $\sim 80 \%)$ were observed on the H4-MCM-41 catalyst, which had the highest amount of $\mathrm{Cr}^{6+}$ and monochromate structures. Catalyst deactivation was not due to coke deposition but, rather, was caused by the formation of inactive $\alpha-\mathrm{Cr}_{2} \mathrm{O}_{3}$ crystal structures.
\end{abstract}

Keywords: isobutane dehydrogenation; $\mathrm{CrO}_{\mathrm{x}} / \mathrm{MCM}-41$; hydrothermal synthesis

\section{ИСПИТУВАњЕ НА ДЕХИДРОГЕНАЦИЈА НА ИЗОБУТАН ВРЗ СКОУ/МСМ-41 КАТАЛИЗАТОР}

\begin{abstract}
Извршена е хидротермичка синтеза на катализатор MCM-41 (Mobil Composition of Matter No. 41) нанесен на хром оксид со различни концентрации (4-10 \% на маса). Целта на ова истражување беше да се определи влијанието на концентрацијата на хром во структурата на катализаторот врз типовите на хромати и врз оксидациските состојби на хром, како и активноста на катализаторот при реакцијата на дехидрогенација на изобутан. Беше покажано дека неактивните кристали на $\alpha-\mathrm{Cr}_{2} \mathrm{O}_{3}$ при дехидрогенацијата на изобутан растат во структурата на катализаторот со зголемување на уделот на хром. Најголемо количество на $\mathrm{Cr}^{6+}$ на површината на катализаторот беше забелеажано кај катализаторот (H4-MCM-41) со $4 \%$ хром на маса. Каталитички тестови $\left(T=600{ }^{\circ} \mathrm{C}, P=\right.$ атмосферски притисок, WHSV $\left.=26 \mathrm{~h}^{-1}\right)$ беа извршени во услови на реактор со фиксирано лежиште. Најголема конверзија на изобутан ( 60\%) и селективност ( $80 \%)$ беа забележани со катализаторот Н4-MCM-41 кој има највисоко количество на $\mathrm{Cr}^{6+}$ и монохроматни структури. Деактивацијата на катализаторот не се должеше на таложење на кокс, туку беше предизвикана од формирањето на неактивни кристални структури на $\alpha-\mathrm{Cr}_{2} \mathrm{O}_{3}$.
\end{abstract}

Клучни зборови: дехидрогенација на изобутан; $\mathrm{CrO}_{x} / \mathrm{MCM}-41$; хидротермичка синтеза

\section{INTRODUCTION}

Isobutene produces gasoline oxygenates, like methyl tert-butyl ether (MTBE) and ethyl tertbutyl ether (ETBE), by reacting with methanol and ethanol. Similarly, isooctane is produced by an alkylation reaction with butane, and antioxidants, such as butylated hydroxytoluene (BHT) and butylated hydroxyanisole (BHA), are synthesized by Friedel-Crafts alkylations with phenols. Butyl rub- 
ber (polyisobutylene, PIB) is synthesized by polymerization. Due to the development of technology, the demand for these valuable products has increased, and as such, isobutane dehydrogenation has become an important reaction. Isobutane dehydrogenation is an endothermic equilibrium-limited reaction. Thus, utilizing a catalyst with high activity, selectivity and stability is important for this reaction. In fact, catalysts with various active components (Pt, V, Cr, Ga, Fe) have been utilized, but the active component $\mathrm{Cr}$ is remarkable because it suppresses coke formation and is inexpensive.

In chromium-based catalysis, chromate types and chromium oxidation states significantly affect the performance of the reactions. These factors vary according to the catalyst preparation method, synthesis starting materials, and the support used. In studies where isobutane dehydrogenation was studied on $\mathrm{CrO}_{\mathrm{x}} / \mathrm{Al}_{2} \mathrm{O}_{3}$ catalysts, it was shown that the most active form was redox $\mathrm{Cr}^{3+}$, formed by reduction of $\mathrm{Cr}^{6+}[1,2]$. In a study conducted by Zhao et al. (2014), chromium was determined to be in the $\mathrm{Cr}^{6+}$ and $\mathrm{Cr}^{3+}$ forms in mesoporous $\mathrm{CrO}_{\mathrm{x}} / \mathrm{Al}_{2} \mathrm{O}_{3}$ catalysts, and chromium showed strong interaction with the alumina support. It was observed that the addition of potassium to the catalysts enhanced isobutene selectivity and catalyst stability [3]. The chromate types were shown to depend on total chromium concentration by Nemykina et al. [4]. Korhonen et al. has also synthesized $\mathrm{CrO}_{\mathrm{x}} /$ zirconia, $\mathrm{CrO}_{\mathrm{x}} /$ alumina and $\mathrm{CrO}_{\mathrm{x}} /$ zirconia-alumina catalysts for isobutane dehydrogenation, and the highest activity was observed in the $\mathrm{CrO}_{\mathrm{x}} /$ zirconia catalyst, which contained the highest amount of $\mathrm{Cr}^{6+}$ [5]. Słoczynski et al. showed that the $\mathrm{Cr}^{6+} / \mathrm{Cr}^{3+}$ ratio decreased with the addition of potassium (K) in the alumina-supported catalyst and did not change in the titanium dioxidesupported catalyst [6]. The addition of $\mathrm{Ca}$ to $\mathrm{Cr}-\mathrm{V}$ binary oxide catalysts was reported, by Deng et al., to increase the active chromium species present in the structure [7]. $\mathrm{CrO}_{x} / \mathrm{Ce}_{0.60} \mathrm{Zr}_{0.35} \mathrm{Y}_{0.05} \mathrm{O}_{2}$ catalysts were synthesized in different chromium concentrations by Wang et al., and the best catalyst performance was obtained in catalyst with $8 \%$ by mass of chromium. Beyond this optimal concentration, inactive $\mathrm{Cr}_{2} \mathrm{O}_{3}$ crystals began to form [8]. Neri et al. synthesized $\gamma$-alumina-supported chromium catalysts by the impregnation method. It was observed that the addition of $\mathrm{Ca}$, up to $2 \%$ by mass, to the catalysts increased the $\mathrm{Cr}^{6+} / \mathrm{Cr}^{3+}$ ratio [9]. Ma et al. showed that, even at high chromium concentrations, on the mesoporous $\mathrm{CrO}_{x} / \mathrm{TiO}_{2}$ catalyst, chromium had a very good distribution, and inactive $\mathrm{Cr}_{2} \mathrm{O}_{3}$ crystals did not form [10]. The addition of $\mathrm{Sn}$ to $\mathrm{CrO}_{x} / \mathrm{Al}_{2} \mathrm{O}_{3}$ catalysts was shown to positively contribute to the formation of active chromium species by Cabrera et al. [11].

MCM-41 is a good support material for Crbased catalysts due to its high surface area, suitable pore structure, and size that allows for hydrocarbon entry. Asghari et al. tested $\mathrm{CrO}_{\mathrm{x}} / \mathrm{MCM}-41$ catalysts, synthesized by hydrothermal and impregnation methods, in oxidative dehydrogenation of ethane. An increase in the $\mathrm{Cr}^{6+} / \mathrm{Cr}^{3+}$ ratio was observed for chromium loading up to $8 \%$ by mass [12]. Ajayi et al. used Cr-MCM-41, V-MCM-41, and Cr-V-MCM-41 catalysts with a metal content of $4 \%$ by mass in n-butane dehydrogenation, and the best performance was observed for $\mathrm{Cr}-\mathrm{V}$ MCM-41 [13]. Ohishi et al. studied the dehydrogenation of ethylbenzene on catalysts with different active metals $(\mathrm{Cr}, \mathrm{Ga}, \mathrm{V}, \mathrm{Fe})$, and the highest conversion and selectivity values were obtained on the Cr-MCM-41 catalyst [14]. In a study performed by our research group, Cr-MCM-41 catalysts containing $3 \% \mathrm{Cr}$ by mass were synthesized by a hydrothermal synthesis method, and the highest isobutane conversions were yielded from the catalyst synthesized by simultaneous addition of the metal solution and silica source. The most active chromate type for isobutane dehydrogenation was determined to be monochromate, and catalyst deactivation was due to the transformation of $\mathrm{Cr}(\mathrm{VI}) \mathrm{O}_{4}$ to the $\mathrm{Cr}_{2} \mathrm{O}_{3}$ crystal phase, which is not coke-based [15]. In another study conducted by our research group, it was shown that the addition of $\mathrm{Ca}$ to the Cr-MCM-41 catalysts caused an increase in mono- and dichromate species in the catalyst structure using a hydrothermal synthesis [16]. In this work, the aim was to synthesize MCM-41supported $\mathrm{CrO}_{\mathrm{x}}$ catalysts with high chromium content $(>3 \%)$ by a hydrothermal synthesis method. The effect of the chromium concentration in the catalyst structure on chromate types, chromium oxidation states, and catalytic activity in isobutane dehydrogenation was investigated.

\section{EXPERIMENTAL}

\subsection{Catalyst synthesis}

In this study, catalysts containing 4, 6, 8, and $10 \%$ chromium by mass were synthesized by a hydrothermal synthesis method. The synthesized catalysts were named $\mathrm{H}^{*}$-MCM-41 (*: 4, 6, 8, 10) to denote the chromium concentrations. In the synthesis studies, the following chemicals were used: $\mathrm{C}_{19} \mathrm{H}_{42} \mathrm{BrN}$ ( $N$-cetyl- $N, N, N$-trimethyl ammonium 
bromide) as the surfactant, sodium silicate solution ( $27 \%$ by mass $\mathrm{SiO}_{2}, 8 \%$ by mass $\mathrm{Na}_{2} \mathrm{O}$, and $65 \%$ by mass $\mathrm{H}_{2} \mathrm{O}$ ) as the source of silica, deionized water as the solvent, and the $\mathrm{Cr}\left(\mathrm{NO}_{3}\right)_{3} \cdot 9 \mathrm{H}_{2} \mathrm{O}$ salt as the chromium source. The surfactant and deionized water were mixed at $30{ }^{\circ} \mathrm{C}$ until a clear mixture was obtained. The silica source and $\mathrm{Cr}\left(\mathrm{NO}_{3}\right)_{3} .9 \mathrm{H}_{2} \mathrm{O}$ dissolved in deionized water were added dropwise and alternately to the surfactant solution. The resulting mixture was adjusted to $\mathrm{pH} 11$. The mixture was placed in a teflon-steel autoclave and kept at $120{ }^{\circ} \mathrm{C}$ for 96 hours. The sample was then removed from the autoclave and was washed until the $\mathrm{pH}$ of the filtrate was about 7. The sample, dried at room temperature, was calcined at $600{ }^{\circ} \mathrm{C}$ for six hours $\left(1^{\circ} \mathrm{C} / \mathrm{min}\right)$ at a dry air flow rate of 135 $\mathrm{ml} / \mathrm{min}$. It was observed that the catalysts, which were green in color after the synthesis, turned yellow after the calcination process, attributed to oxidation of the chromium following calcination. Characterization studies were performed with nitrogen adsorption/desorption (Quantochrome, Autosorb-1), X-ray diffraction (Rigaku Brand D /MAX 2200), X-ray photoelectron spectroscopy (SPECS), and diffuse reflactance UV-vis (Perkin Elmer RSA-PE-20) analysis. The decomposition of hydrocarbons in the reaction medium at high temperatures may cause carbonaceous deposits (coke). In our study, thermal gravimetric analysis (Perkin Elmer Diamond DSC) was used to determine the amount of coke deposition causing catalyst deactivation.

\subsection{Catalytic tests}

Catalytic tests were performed under fixed bed reactor conditions. The quartz glass reactor (1 $\mathrm{m}$ long and $0.65 \mathrm{~cm}$ in diameter), with a glass sieve in the middle, was placed in a tube furnace (Protherm Furnace Model PTF 12/38/250). Catalytic tests were carried out with $0.1 \mathrm{~g}$ of catalyst at $600{ }^{\circ} \mathrm{C}$ and atmospheric pressure. Nitrogen gas was passed through the quartz glass reactor until the reaction temperature was reached. When the reactor reached a temperature of $600{ }^{\circ} \mathrm{C}$, the nitrogen gas flow was cut off, and the pure isobutane feed $(20 \mathrm{ml} / \mathrm{min})$ was sent to the system. Gas samples, taken from the system at specified periods, were analyzed in a gas chromatography device (SRI 8610C-silica column). Isobutane conversion and isobutene selectivity values were determined from the obtained results.

\section{RESULTS AND DISCUSSIONS}

In the study, $\mathrm{CrO}_{\mathrm{x}} / \mathrm{MCM}-41$ catalysts containing different amounts of chromium were synthesized by a hydrothermal synthesis method. After characterization, catalytic test studies were performed with selected catalysts. The results of the characterization and catalytic test studies are presented, with their discussions, in the following sections.

\subsection{Characterization of synthesized catalysts}

BET (Brunauer-Emmett-Teller) surface areas of the catalysts with different chromium concentrations, prepared by hydrothermal synthesis, are shown in Table 1.

Table 1

BET Surface areas of synthesized catalysts

\begin{tabular}{cc}
\hline Catalyst & BET surface area $\left(\mathbf{m}^{2} / \mathbf{g}\right)$ \\
\hline MCM-41 & 1250 \\
H4-MCM-41 & 1188 \\
H6-MCM-41 & 719 \\
H8-MCM-41 & 695 \\
H10-MCM-41 & 542 \\
\hline \hline
\end{tabular}

From Table 1, it is seen that the surface area of the catalyst, which has a chromium content of 4 $\%$ by mass, is approximately two times greater than that of the catalyst with $10 \%$ chromium. As the amount of chromium in the structure increased, small chromium oxide crystals $\left(\mathrm{CrO}_{\mathrm{x}}\right)$ merged and formed large crystals $\left(\alpha-\mathrm{Cr}_{2} \mathrm{O}_{3}\right)$. Thus, some of the pores closed, and a decrease in the catalyst surface area occurred [17].

Nitrogen adsorption/desorption isotherms of all synthesized catalysts were observed as Type IV isotherms. The pore size distribution curves, determined by the BJH method between 10 and $40 \AA$, indicated that the structure consisted mainly of mesopores. The isotherm and pore diameter distribution curves for the catalyst (H4-MCM-41) containing $4 \%$ by mass of chromium is shown, as an example, in Figure 1. 


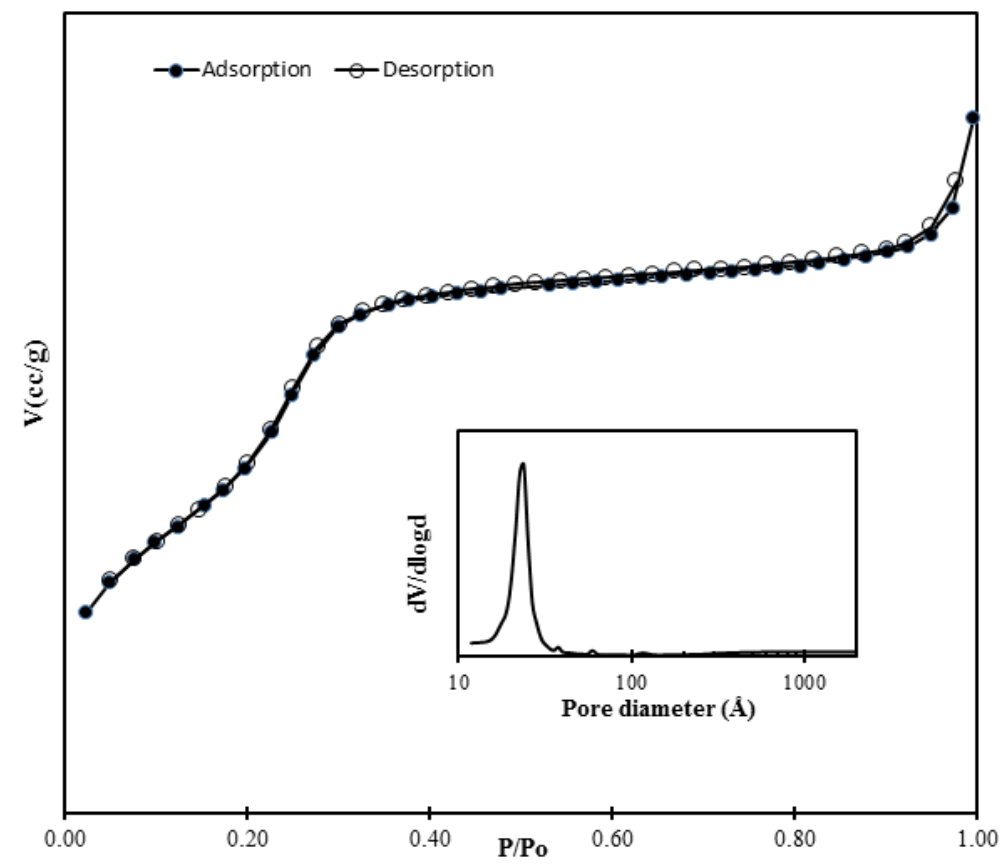

Fig. 1. The adsorption/desorption isotherm and pore size distribution curve (inset) for the catalyst containing $4 \%$ chromium by mass (H4-MCM- 41 )
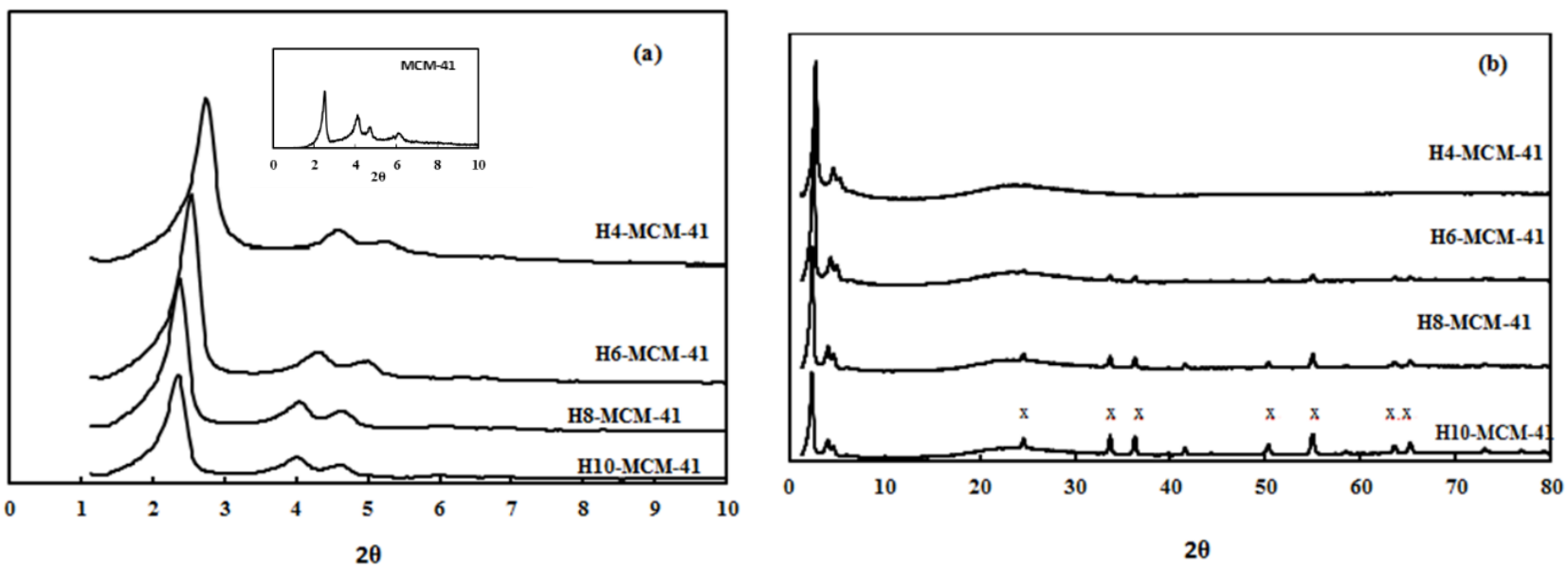

Fig. 2. Low angle (a) and high angle (b) XRD diffraction patterns of synthesized catalysts (x: $\alpha-\mathrm{Cr}_{2} \mathrm{O}_{3}$ crystals)

The results of low angle and high angle XRD analysis of MCM-41-supported catalysts containing 4, 6, 8, and $10 \%$ chromium are given in Figure 2.

In Figure 2, 4 characteristic peaks $\left(2 \theta: 2.52^{\circ}\right.$, $\left.4.18^{\circ}, 4.76^{\circ}, 6.14^{\circ}\right)$ are seen, characterizing the regular hexagonal pore structure of MCM-41 in all catalysts. The metal added to the structure did not cause any serious degradation in the regular pore structure of MCM-41, but the main peak intensity for the H10-MCM-41 catalyst decreased. Particularly for catalysts with high metal concentrations, shifts were observed in peaks of pure MCM-41. In hydrothermal syntheses of mesoporous silica materials, metal loading affects the micelle formation mechanism.
This causes changes in structural parameters, such as interplanar spacing and wall thickness. As a result of these structural changes, peaks of the pure MCM-41 structure shift $[18,19]$. In the high-angle XRD diffraction patterns of the synthesized catalysts, strong peaks characterizing the $\mathrm{Cr}_{2} \mathrm{O}_{3}$ crystals (20: $24.5^{\circ}, 33.6^{\circ}, 36.2^{\circ}, 50.2^{\circ}, 54.9^{\circ}, 63.5^{\circ}, 65.1^{\circ}$ ) were seen at high chromium concentrations. However, peaks characterizing $\mathrm{Cr}_{2} \mathrm{O}_{3}$ crystals were not observed in the catalyst containing $4 \%$ chromium (H4-MCM-41). These results indicate that chromium oxides are dispersed as small crystals in the structure of the H4-MCM-41 catalyst.

The coordination and oxidation states of chromium in the catalyst structures are known to 
be the most important parameters affecting dehydrogenation activity [3]. XPS analyses were performed to obtain information about the oxidation
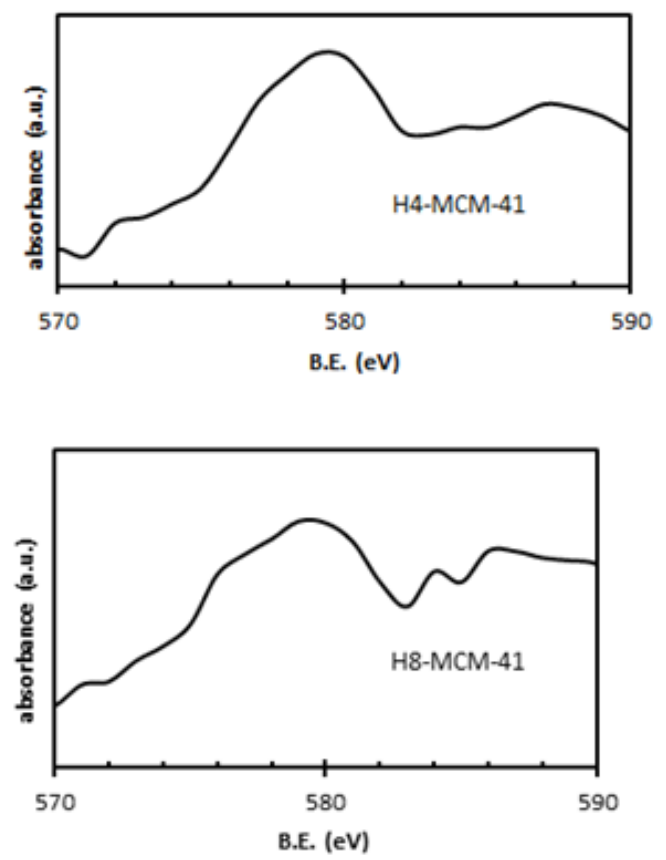

state of chromium on the catalyst surface. Cr2p curves, obtained as a result of these analyses, are shown in Figure 3.
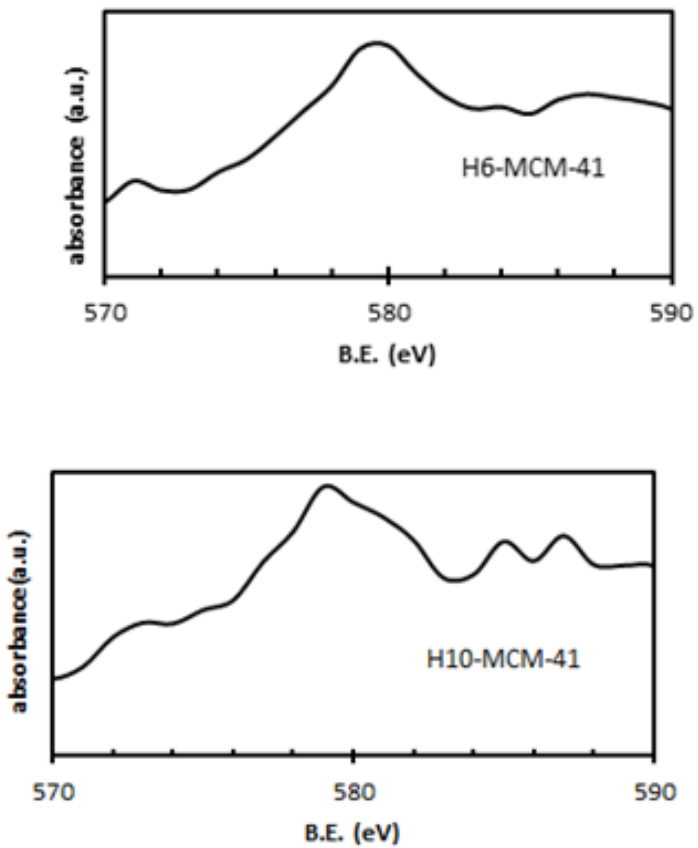

Fig. 3. Cr2p curves, obtained by XPS analysis, of synthesized catalysts

Figure 3 shows that the peak around $579 \mathrm{eV}$, which represents the presence of $\mathrm{Cr}^{6+}$ in chromates, is present in all catalysts. The peak observed between 584 and $585 \mathrm{eV}(2 \mathrm{p} 1 / 2)$ in the $\mathrm{Cr} 2 \mathrm{p}$ curves indicates the presence of $\mathrm{Cr}^{3+}$. The percentages of $\mathrm{Cr}^{6+}$ forms, compared to total $\mathrm{Cr}^{6+}$ and $\mathrm{Cr}^{3+}$ content, were determined from the height of peaks representing the presence of $\mathrm{Cr}^{6+}$ and $\mathrm{Cr}^{3+}$ (Table 2).

\section{Table 2}

Percentages of $\mathrm{Cr}^{6+}$ in the structure of catalysts for total $\mathrm{Cr}^{6+}$ and $\mathrm{Cr}^{3+}$ content

\begin{tabular}{cc}
\hline \hline Catalyst & $\mathbf{C r}^{\mathbf{6 +}} /\left(\mathbf{C r}^{\mathbf{3 +}}+\mathbf{C r}^{\mathbf{6 +}}\right)(\boldsymbol{\%})$ \\
\hline H4-MCM-41 & 97 \\
H6-MCM-41 & 92 \\
H8-MCM-41 & 88 \\
H10-MCM-41 & 81 \\
\hline \hline
\end{tabular}

The highest percentage of $\mathrm{Cr}^{6+}$ was observed in the catalyst containing $4 \%$ chromium (H4MCM-41). As the chromium loading increased, the amount of $\mathrm{Cr}^{6+}$ in the catalyst structure decreased. The $\mathrm{Cr} / \mathrm{Si}$ ratios, determined from XPS analysis, are shown in Table 3 together with the actual $\mathrm{Cr} / \mathrm{Si}$ ratios added during the synthesis.

Table 3

$\mathrm{Cr} / \mathrm{Si}$ ratios determined on the catalyst surface (XPS analysis)

\begin{tabular}{ccc}
\hline \hline \multirow{2}{*}{ Catalyst } & Analysis & Synthesis \\
\cline { 2 - 3 } & $\mathbf{C r} / \mathbf{S i}$ & $\mathbf{C r} / \mathbf{S i}$ \\
\hline H4-MCM-41 & 0.031 & 0.048 \\
H6-MCM-41 & 0.032 & 0.074 \\
H8-MCM-41 & 0.030 & 0.100 \\
H10-MCM-41 & 0.040 & 0.130 \\
\hline \hline
\end{tabular}

In all synthesized catalysts, $\mathrm{Cr} / \mathrm{Si}$ ratios determined by XPS analysis were found to be lower than the ratios added during the synthesis. This shows that chromium was placed deep into the pores, rather than on the surface. The two $\mathrm{Cr} / \mathrm{Si}$ ratios were the closest to each other for the catalyst with $4 \%$ by mass of chromium. All characterization studies showed that inactive $\mathrm{Cr}_{2} \mathrm{O}_{3}$ crystals increased with increasing metal concentrations. During the calcination process, although small monochromates, in the form of small crystals, are transported to the surface with help from water in 
the structure, large crystals are not [20]. Further, only surface concentrations are determined by XPS analysis, but bulk concentrations cannot be measured. Due to the inability of large crystals to be carried to the surface, the increase in metal concentration did not cause the expected increase in the $\mathrm{Cr} / \mathrm{Si}$ ratio, as determined in the XPS analyses.
$\mathrm{Cr}^{6+}$ can be found in three oxide forms: monochromate, dichromate, and polychromate. Monochromates are known to be the most active chromate form in isobutane dehydrogenation [15]. DR$\mathrm{UV}$-vis measurements were performed to determine the chromate forms in the structure, and the results are given in Figure 4.

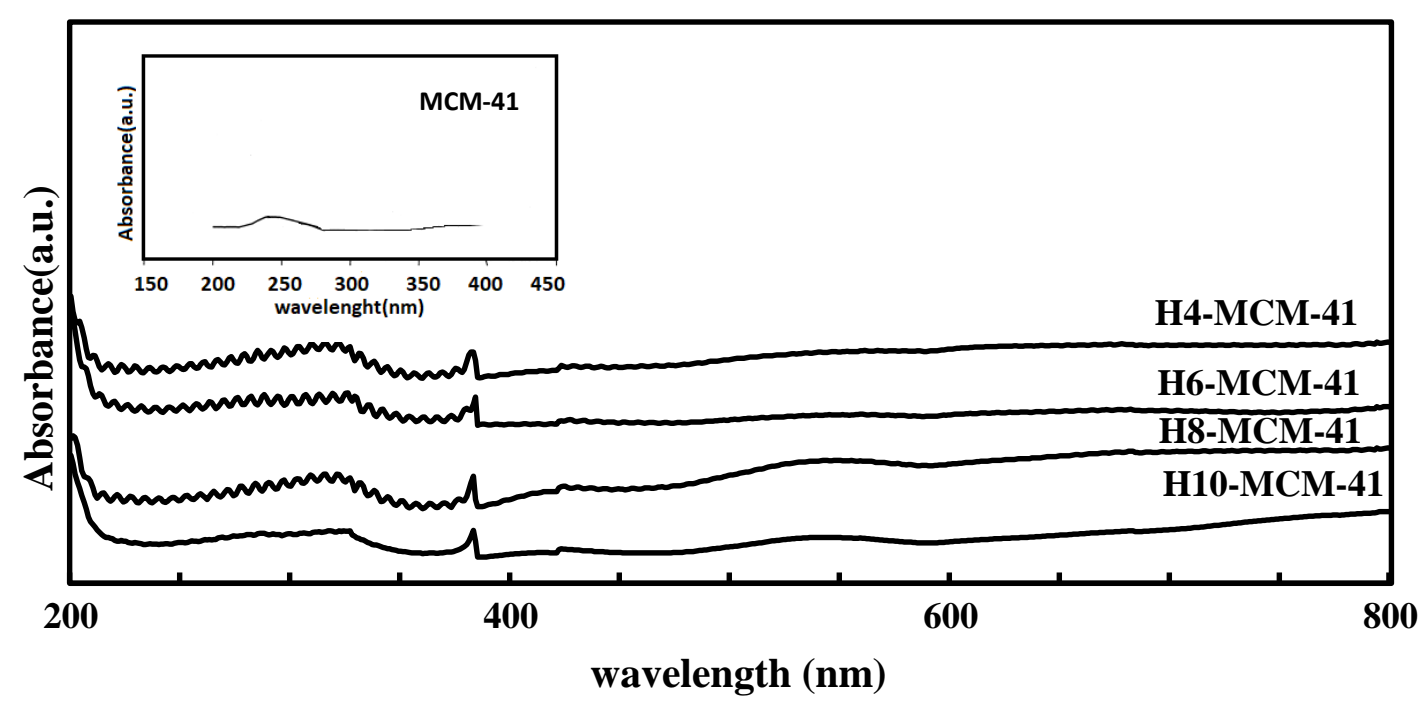

Fig. 4. DR-UV-vis spectra of $\mathrm{CrO}_{\mathrm{x}} / \mathrm{MCM}-41$ catalysts

It was seen from Figure 4 that DR-UV-vis spectra are very sensitive to the presence of extra framework and the coordination of Cr in MCM-41 [21]. MCM-41 has a characteristic distribution between $225-275 \mathrm{~nm}$. This characteristic distribution disappeared upon the addition of $\mathrm{Cr}$ in all the synthesized catalysts. Peak formations around 320 and $380 \mathrm{~nm}$ refer to $\mathrm{O}-\mathrm{Cr}^{6+}$ charge transfer in dichromate and monochromate species, respectively. The peak observed around $430 \mathrm{~nm}$ belongs to the polychromate. Additionally, the elbow formation around $600 \mathrm{~nm}$ refers to $\mathrm{O}-\mathrm{Cr}^{3+}$ charge transfer within the $\mathrm{Cr}_{2} \mathrm{O}_{3}$ crystal. Calculations using the peak areas for the monochromates showed that the amount of monochromate in the H4MCM-41 catalyst was about $15 \%$ higher than that of the H10-MCM-41 catalyst.

\subsection{Catalytic test studies}

Literature has reported that a high amount of $\mathrm{Cr}^{6+}$ in the catalyst structure positively affects isobutane conversion and isobutene selectivity $[15,16]$. In addition, monochromates were determined to be the most active chromates. Characterization studies showed that $\mathrm{Cr}_{2} \mathrm{O}_{3}$ crystals, which were determined to be inactive for the reaction, increased in the structure as chromium concentration increased. For the catalytic tests, catalysts with a high amount of both $\mathrm{Cr}^{6+}$ and monochromate were selected (H4-MCM-41 and H6-MCM41). For comparison, catalytic tests were carried out with the catalyst that had the largest amount of inactive $\mathrm{Cr}_{2} \mathrm{O}_{3}$ crystals (H10-MCM-41). Isobutane conversion and isobutene selectivity values were calculated by using the following equations.

$$
\begin{gathered}
\text { isobutane conversion }(\%)= \\
\frac{\left(i-C_{4} H_{10, \text { initial }}\right)-\left(i-C_{4} H_{10, \text { final }}\right)}{\left(i-C_{4} H_{10, \text { initial }}\right)} \times 100
\end{gathered}
$$

isobutene selectivity $(\%)=$

$$
=\frac{\left(i-C_{4} H_{8, \text { formed }}\right)}{\left(i-C_{4} H_{10, \text { initial }}\right)-\left(i-C_{4} H_{10, \text { final }}\right)} \times 100
$$

The isobutane conversion and isobutene selectivity values determined by catalytic tests are given in Figures 5-7. 


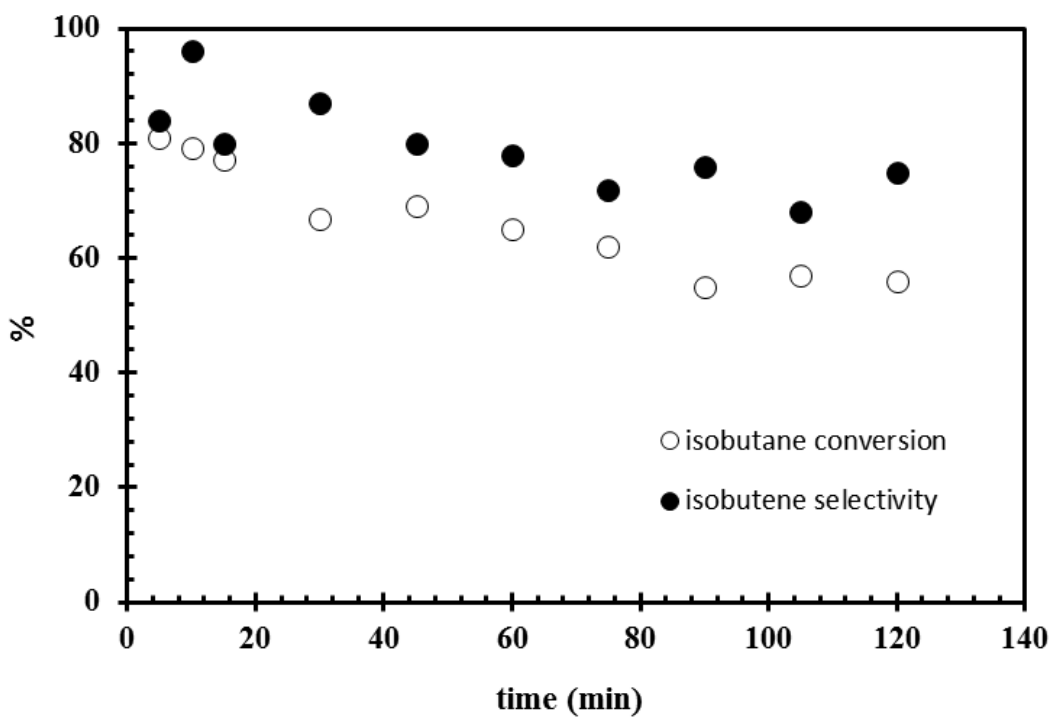

Fig. 5. Isobutane conversion and isobutene selectivity values determined on the H4-MCM-41 catalyst

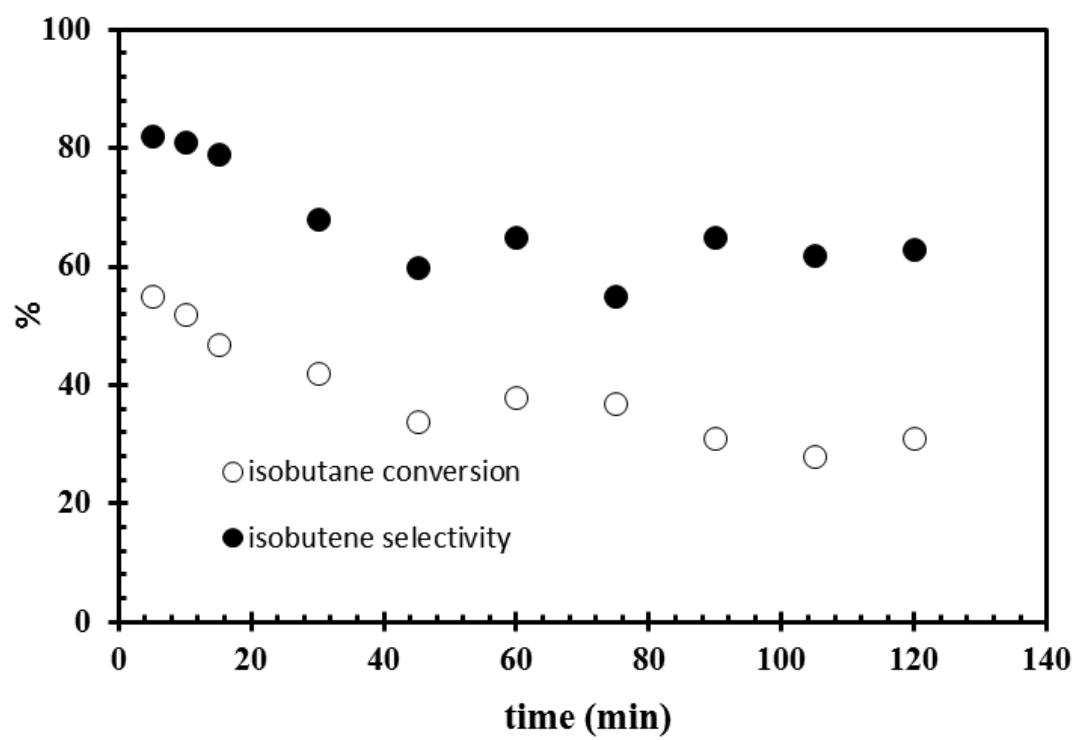

Fig. 6. Isobutane conversion and isobutene selectivity values determined on the H6-MCM-41 catalyst

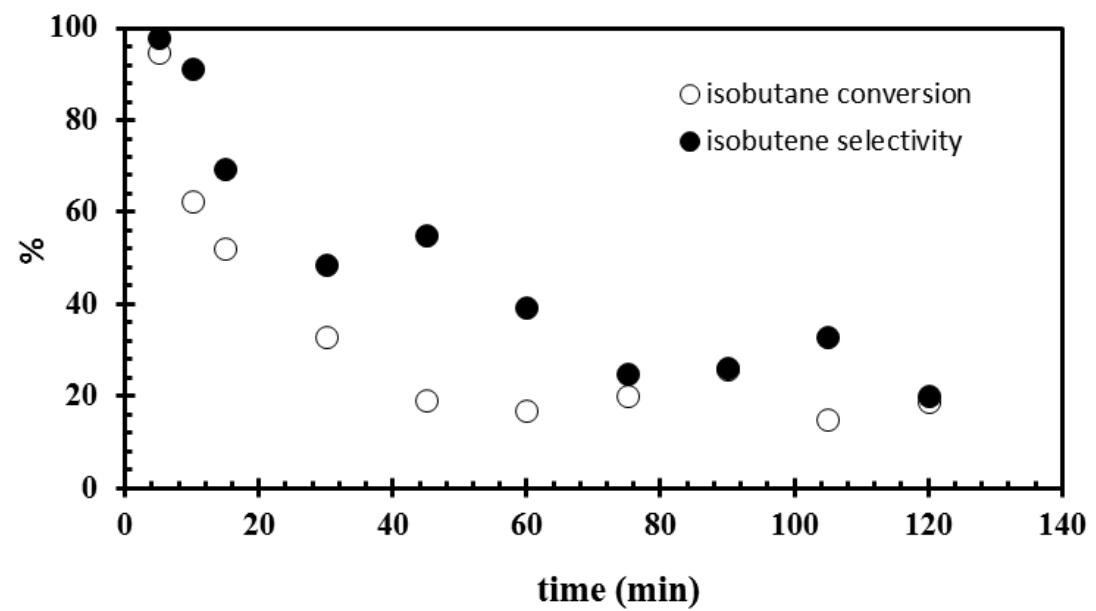

Fig. 7. Isobutane conversion and isobutene selectivity values determined on the H10-MCM-41 catalyst 
The conversion values of the H4-MCM-41 catalyst, which were around $80 \%$ at the beginning of the reaction, decreased to about $60 \%$ as the reaction proceeded. The isobutene selectivity values were predicted to be approximately $80 \%$ after 10 minutes. For the H6-MCM-41 catalyst, the isobutane conversion values remained at about $36 \%$ after 40 minutes. Isobutene selectivity was determined to be around $60 \%$ after 40 minutes. It was observed that the initial high conversion and selectivity values decreased rapidly for the H10-MCM41 catalyst. After 60 minutes, the conversion and selectivity values were approximately 20 and 25 $\%$, respectively. As expected, relatively low conversion and selectivity values were determined for the catalyst containing high amounts of $\mathrm{Cr}_{2} \mathrm{O}_{3}$ crystals, compared with the other two catalysts. The highest conversion and selectivity values were detected on the H4-MCM-41 catalyst, which had the highest $\mathrm{Cr}^{6+}$ amount and the most monochromate structures. For comparison, the support MCM-41 exhibited approximately $3 \%$ isobutane conversion under the same catalytic conditions.

When the pure isobutane is used as the feed stream, the side reactions (2-3) that are likely to occur, in addition to the main reaction (1), are given below.

$$
\begin{aligned}
& i-\mathrm{C}_{4} \mathrm{H}_{10} \leftrightarrow \mathrm{i}-\mathrm{C}_{4} \mathrm{H}_{8}+\mathrm{H}_{2} \\
& \overline{i-\mathrm{C}_{4} \mathrm{H}_{10}+\mathrm{H}_{2} \leftrightarrow \mathrm{i}-\mathrm{C}_{3}} \mathrm{H}_{8}+\mathrm{CH}_{4} \\
& i-\mathrm{C}_{4} \mathrm{H}_{10} \leftrightarrow \mathrm{i}-\mathrm{C}_{3} \mathrm{H}_{6}+\mathrm{CH}_{4}
\end{aligned}
$$

As well as isobutene selectivity, propane, propene, and methane selectivity values were plotted versus the reaction time for the H4-MCM-41 catalyst in Figure 8.

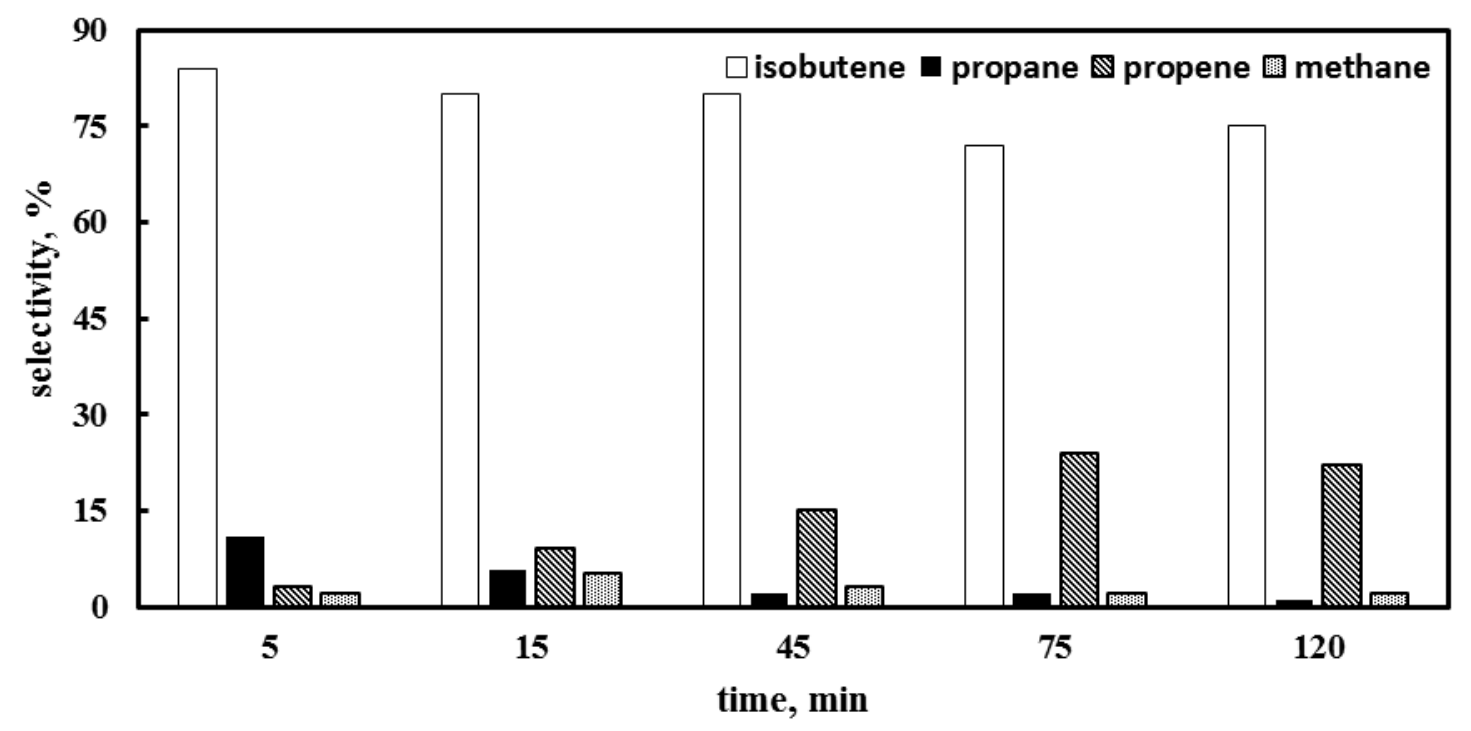

Fig. 8. Selectivity values determined on the H4-MCM-41 catalyst

A high amount of propane was observed in the first five minutes of the reaction. After this time, the formation of propane decreased, and almost no propane was observed at the end of the reaction. After five minutes, the observation of propene formation began and continued to increase until 75 minutes of total reaction time. This indicated that side reaction 3 occurred after the first five minutes of the reaction. The product, hydrogen, was initially used for the formation of active, unsaturated $\mathrm{Cr}^{3+}$ by reducing $\mathrm{Cr}^{6+}$ and, in parallel, was also used for the isobutane hydrogenation reaction (reaction 2). When the reaction proceeded, the catalyst-hydrogen interaction further increased, and the use of hydrogen for isobutane hydrogenation decreased. With the progress of this reaction, the cracking of isobutane (reaction 3 ) became important and continued until the end of the reaction.

The catalytic tests carried out with all catalysts showed a decrease in isobutane conversion values during the reaction. The change of the initial yellow color of the catalyst to green was explained by a decrease in the amount of $\mathrm{Cr}^{6+}$ in the structure [2]. Literature reported that isobutane dehydrogenation was carried out by a mechanism based on the adsorption of hydrogen in the isobutane structure to unsaturated chromium atoms on the catalyst surface [22]. During the reaction, the 
unsaturated chromium on the catalyst surface converted to the crystal $\alpha-\mathrm{Cr}_{2} \mathrm{O}_{3}$ [1]. Since $\alpha-\mathrm{Cr}_{2} \mathrm{O}_{3}$ cannot adsorb hydrogen in the isobutane, this structure has no contribution to dehydrogenation activity [23]. TGA (Thermal Gravimetric Analysis) analyses carried out after the reaction showed that the formation of coke on the H4-MCM-41 catalyst was quite low ( $\sim 0.1 \%$ by mass). The decrease in isobutane conversion and isobutene selectivity values during the reaction was thought to be the result of an increase in the amount of $\alpha-\mathrm{Cr}_{2} \mathrm{O}_{3}$ crystal structure in the catalyst.

\section{CONCLUSION}

In this study, MCM-41-supported catalysts at different chromium concentrations were synthesized by a hydrothermal method. Characterization studies and catalytic tests were conducted on the catalysts. The presence of $\mathrm{Cr}^{6+}$ and monochromate structures was determined in the structures of all synthesized catalysts, and the highest ratios were observed in the catalyst containing $4 \%$ by mass of chromium. The highest isobutane conversion and isobutene selectivity values were also obtained by the same catalyst. As the amount of metal increased, the amount of crystal $\alpha-\mathrm{Cr}_{2} \mathrm{O}_{3}$ increased and the catalyst activity decreased, accordingly. The dehydrogenation reaction product, hydrogen, was initially used both for the formation of active, unsaturated $\mathrm{Cr}^{3+}$, by reducing $\mathrm{Cr}^{6+}$ in the catalyst structure, and for the isobutane hydrogenation. When the reaction proceeded, hydrogen was used for isobutane cracking instead of isobutane hydrogenation. Thus, during the reaction, the unsaturated $\mathrm{Cr}^{3+}$ on the surface converted into the inactive crystal $\alpha-\mathrm{Cr}_{2} \mathrm{O}_{3}$. The decrease in activity was not caused by coke $(<0.1 \%)$ but was thought to be due to an increase in the amount of $\alpha-\mathrm{Cr}_{2} \mathrm{O}_{3}$ in the catalyst structure. The most suitable chromium concentration was determined to be $4 \%$ by mass for the MCM-41-supported catalysts, synthesized by a hydrothermal synthesis method.

\section{REFERENCES}

[1] V. Z. Fridman, R. Xing, Investigating the $\mathrm{CrO}_{x} / \mathrm{Al}_{2} \mathrm{O}_{3}$ dehydrogenation catalyst model: II. Relative activity of the chromium species on the catalyst surface, Appl. Catal. A, 530, 25, 154-165 (2017). DOI: https://doi.org/10.1016/j.apcata.2016.11.024

[2] V. Z. Fridman, R. Xing, M. Severance, Investigating the $\mathrm{CrO}_{\mathrm{x}} / \mathrm{Al}_{2} \mathrm{O}_{3}$ dehydrogenation catalyst model: I. Identification and stability evaluation of the $\mathrm{Cr}$ species on the fresh and equilibrated catalysts, Appl. Catal. A, 523, 3953(2016).

DOI: https://doi.org/10.1016/j.apcata.2016.05.008

[3] H. Zhao, H. Song, Z. Miao, L. Chou, Isobutane dehydrogenation over chromia alumina catalysts prepared from MIL-101: Insight into chromium species on activity and selectivity, J. Energy. Chem., 23, 6, 708-716 (2014).

DOI: https://doi.org/10.1016/S2095-4956(14)60203-5

[4] E. I. Nemykina, N. Pakhomov, V. V. Danilevich, V. A. Rogov, V. I. Zaikovskii, T. V. Larina, V. V. Molchanov, Effect of chromium content on the properties of a microspherical alümina-chromium catalyst for isobutane dehydrogenation prepared with the use of a centrifugal thermal activation product of gibbsite, Kinet. Catal., 51, 6, 898-906 (2010).

[5] S. T. Korhonen, S. M. K. Airaksinen, M. A. Banares, A. O. Krause, Isobutane dehydrogenation on zirconia-, alümina-, and zirconia/alümina-supported chromia catalyst, Appl. Catal. A, 333, 30-41 (2007).

DOI: https://doi.org/10.1016/j.apcata.2007.08.040

[6] J. Sloczynski, B. Grzybowska, A. Kozlowska, K. Samson, R. Grabowski, Effect of potassium on physicochemical properties of $\mathrm{CrO}_{x} / \mathrm{Al}_{2} \mathrm{O}_{3}$ and $\mathrm{CrO}_{\mathrm{x}} / \mathrm{TiO}_{2}$ catalysts for oxidative dehydrogenation of isobutane: The role of oxygen chemisorption, Catal. Today, 169, 29-35 (2011). DOI: https://doi.org/10.1016/j.cattod.2010.10.096

[7] J. Deng, L. Zhang, C. Liu, Y. Xia, H. Dai, Single-crystalline mesoporous $\mathrm{CaO}$ supported $\mathrm{Cr}-\mathrm{V}$ binary oxides: Highly active catalysts for the oxidative dehydrogenation of isobutene, Catal. Today, 164, 1, 347-352 (2011).

DOI: https://doi.org/10.1016/j.cattod.2010.10.023

[8] G. Wang, H. Dai, L. Zhang, J. Deng, C. Liu, H. He, C. T. $\mathrm{Au}, \mathrm{CrO} \times$ /nano-Ce0.60Zr0.35Y0.05O2 catalysts that are highly selective for the oxidative dehydrogenation of isobutane to isobutene, Appl. Catal. A, 375, 2, 272-278 (2010). DOI: https://doi.org/10.1016/j.apcata.2010.01.005

[9] G. Neri, A. Pistone, S. de Rossi, E. Rombi, C. Milone, S. Galvagno, Ca-doped chromium oxide catalysts supported on $\mathrm{Al}_{2} \mathrm{O}_{3}$ for the oxidative dehydrogenation of isobutane, Appl. Catal. A, 260, 75-86 (2004). DOI: https://doi.org/10.1016/j.apcata.2003.10.002

[10] F. Ma, S. Chen, Y. Wang, F. Chen, W. Lu, Characterization of redox and acid properties of mesoporous $\mathrm{Cr}-\mathrm{TiO}_{2}$ and its efficient performance for oxidative dehydrogenation of propane, Appl. Catal. A, 427-428, 145-154 (2012).

DOI: https://doi.org/10.1016/j.apcata.2012.03.043

[11] F. Cabrera, D. Ardissone, O. F. Gorriz, Dehydrogenation of propane on chromia/alümina catalysts promoted by tin, Catal. Today, 133-135, 800-804 (2008).

DOI: https://doi.org/10.1016/j.cattod.2007.12.039

[12] E. Asghari, M. Haghighi, F. Rahmani, $\mathrm{CO}_{2}$-oxidative dehydrogenation of ethane to ethylene over $\mathrm{Cr} / \mathrm{MCM}-41$ nanocatalyst synthesized via hydrothermal/impregnation methods: Influence of chromium content on catalytic properties and performance, J. Mol. Catal. A-Chem., 418-419, 115-124 (2016).

DOI: https://doi.org/10.1016/j.molcata.2016.03.033

[13] B. P. Ajayi, B. R. Jermy, K. E. Ogunronbi, B. A. Abussaud, S. Al-Khattaf, n-butane dehydrogenation over 
mono and bimetallic MCM-41 catalysts under oxygen free atmosphere, Catal. Today, 204, 189-196 (2013). DOI: https://doi.org/10.1016/j.cattod.2012.07.013

[14] Y. Ohishi, T. Kawabata, T. Shishido, K. Takaki, Q. Zhang, Y. Wang, K. Takehira, Dehydrogenation of ethylbenzene with $\mathrm{CO}_{2}$ over Cr-MCM-41 catalyst, $J$. Mol. Catal. A-Chem., 230, 49-58(2005). DOI: https://doi.org/10.1016/j.molcata.2004.12.006

[15] S. Kilicarslan, M. Dogan, T. Dogu, Cr incorporated MCM-41 type catalysts for isobutane dehydrogenation and deactivation mechanism, Ind. End. Chem. Res., 52, 10, 3674-3682 (2013). DOI: https://doi.org/10.1021/ie302543c

[16] S. Çetinyokuş Kilıçarslan, M. Doğan, T. Doğu, Synthesis and characterization of Ca-Cr-MCM-41 catalysts for isobutane dehydrogenation, J. Fac. Eng. Archit. Gazi Univ., 29, 3, 459-467 (2014).

[17] H. Zhao, H. Song, L. Xu, L. Chou, Isobutane dehydrogenation over the mesoporous $\mathrm{Cr}_{2} \mathrm{O}_{3} / \mathrm{Al}_{2} \mathrm{O}_{3}$ catalysts synthesized from a metal-organic framework MIL-101, Appl. Catal., A, 456, 188-196 (2013). DOI: https://doi.org/10.1016/j.apcata.2013.02.018

[18] S. Balc1, S. Yüksel, Effect of surface sulfanation on the ordered and textural properties of vanadium and iron containing SBA-15, GU J. Sci. PartA: Engineering and Innovation, 4, 4, 85-92 (2017).

[19] Y. Li, J. Wang, C. Ding, L. Ma, Y. Xue, J. Guo, S. Wang, Y. Meng, K. Zhang, P. Liu, Effects of cobalt addition on the structure and properties of Ni-MCM-41 for the partial oxidation of methane to syngas, Royal Society of Chem., 9, 25508-25517(2019). DOI: $10.1039 / \mathrm{C} 9 \mathrm{RA} 03534 \mathrm{~F}$

[20] N. Maxim, H. C. L. Abbenhuis, P. J. Stobbelaar, B. L. Mojet, Chromium Silsesquioxane Based Synthesis and Characterization of a Microporous Cr-Si-O Material, Phys. Chem. Chem. Phys., 1, 4473-4477 (1999). http://pascalfrancis.inist.fr/vibad/index.php?action=getR ecordDetail\&idt $=1988180$

[21] S. H. Liu, Y. J. Huang, K. S. Lin, M. C. Hsiao, photodecomposition of water catalyzed by $\mathrm{Zr}$ - and $\mathrm{Ti}-$ MCM-41, Energy Sources, 25, 6, 591-596 (2003).

[22] S. Çetinyokuş Kılıçarslan, Reaction mechanism research for isobutane dehydrogenation, J. Fac. Eng. Archit. Gazi Univ., 31, 2, 221-229 (2016).

[23] V. Z. Fridman, R. Xing, Deactivation studies of the $\mathrm{CrO}_{\mathrm{x}} / \mathrm{Al}_{2} \mathrm{O}_{3}$ dehydrogenation catalysts under cyclic redox conditions, Ind. Eng. Chem. Res., 56, 28, 79377947 (2017).

DOI: https://doi.org/10.1021/acs.iecr.7b01638 